\title{
Kernos
}

Revue internationale et pluridisciplinaire de religion grecque antique

8| 1995

Varia

\section{The Politicus Myth (268D-274E) and the History of Religion}

\section{Giovanni Casadio}

\section{OpenEdition \\ Journals}

\section{Electronic version}

URL: http://journals.openedition.org/kernos/589

DOI: 10.4000/kernos.589

ISSN: 2034-7871

\section{Publisher}

Centre international d'étude de la religion grecque antique

\section{Printed version}

Date of publication: 1 January 1995

Number of pages: 85-95

ISSN: 0776-3824

\section{Electronic reference}

Giovanni Casadio, «The Politicus Myth (268D-274E) and the History of Religion », Kernos [Online], 8 | 1995, Online since 11 April 2011, connection on 01 May 2019. URL : http:// journals.openedition.org/kernos/589; DOI : 10.4000/kernos.589 


\section{The Politicus Myth (268 D - 274 E) and the History of Religions*}

Platonic scholars generally emphasize that "god" (ó $\theta \varepsilon o ́ s)$ has no ontological preeminence in Plato's system ${ }^{1}$. This view is in fact well grounded in Plato's doctrine according to which every entity is ontologically and axiologically subordinate to the Ideas, in primis the Idea of Good. Even in the Timaeus God may be regarded as a "factor of rational causation"2 who looks to the Ideas for his demiurgic activity. Having in this way made allowance for the dialectical truth, we will not deny that the god of Timaeus and the god of the Politicus myth, as well as - mutatis mutandis - the gods of the Laws (bk. X), are majestic characters whose role may appear analogous to that played by God (i.e. the Supreme Being) in a positive religion. So it may be interesting for those concerned with the history of religions to tackle a Platonic god - in this case the god of the Politicus myth- in the same way as they would deal with other cult realities of ancient religion.

\section{God: his characterisation from a comparative point of view}

If we wonder what kind of god is the one acting on the stage of this tantalizing myth, we would find that he is a many-sided figure. First he comes on the scene with the familiar and reassuring features of Zeus. The god (o $\theta \varepsilon$ có) who, "bearing witness for Atreus", is responsible "for the change in the setting and rising of the sun and stars" (269 A 1-5) is obviously the sky-god and supreme head of the Olympian pantheon. According to a mythical tradition first

* This paper was delivered at the triennal session of the International Plato Society (III Symposium Platonicum, Bristol, 25-30 August 1992). I thank Dr Marcello Rosetti for his diligence in correcting my English and Prof. Christopher Rowe for his noncommittal hospitality in such a philosophical ambiance. A Spanish version was read at the Curso-Coloquto Internacional "Orlente y Grécia: mito y religión" (Valladolid, 15-17 nov. 1993, convenor E. Suárez de la Torre).

1 See e.g. R.D. MOHR, The Platonic Cosmology, Leiden, 1985, p. 15-18, and A. BORTOLOTTI, La religione nel pensiero di Platone dai primi dialoghi al Fedro, Firenze, 1986, esp. p. 15 and 234.

2 H. CHERNISS, The Sources of Evil according to Plato, in PAPbS (1954) [= Selected Papers, Leiden, 1977, p. 254]. Cf. MOHR, op. cit. (n. 1), p. 22-23: "If the Demiurge bears a resemblance to any of the gods of the Western theistic traditions, it is to the god of the ontological argument, or at least of those variants of the argument, like that in Descartes's Third Meditation, which employ the principle of sufficient reason." 
attested in Euripides ${ }^{3}$, Zeus made the sun reverse his course in order to demonstrate the priority of a rightful claim even to the prejudice of the cosmic order, in other words to validate the appalling maxim fiat iustitia, pereat mundus $s^{4}$. We may admit that "Plato's real theological beliefs had little in common with the ancient religion" ${ }^{15}$; but such a Zeus, so eager to interfere in human and cosmic affairs, looks really sympathetic to Plato's uncompromising ethical fundamentalism.

Prima facie the provident god (ó Aróc), who (269 C 4-5) helps to guide

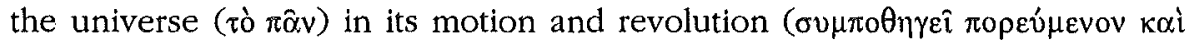
$\sigma \nu \gamma \kappa v \kappa \lambda \varepsilon i \hat{)}$ ), seems cognate to the watchful god of the Argive saga. If in fact it is true that the germs of the Politicus myth are to be found in a presumably very old tradition, there Plato operates a significant shift of emphasis. In the time of Atreus the sun's change of direction took place following the god's active intervention. In Plato's phantasy the change in the movement of the whole (leading to changes in the movement of the parts, in primis the sun and the stars) occurs at the very moment that the god lets go the helm leaving the world to itself ( $269 \mathrm{C} \mathrm{5}$ ). So Plato's god seems to keep his distance from the Zeus of the standard Greek religion.

Let us now examine the activities that this god carries out in positive way (his intervention in this world), leaving for later the activities that he carries out in negative way (his non-intervention). God acts on the world in two stages. In the beginning he constructed ( $\sigma \nu v \alpha \rho \mu o ́ \sigma \alpha \nu \tau o \varsigma: 269$ D 1) or fashioned

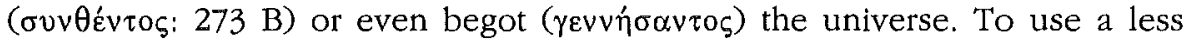

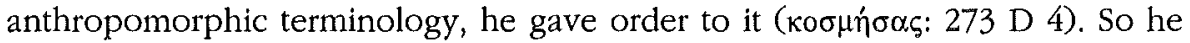
may be called "maker, creator" ( $\delta$ trovprós: 270 A 5) or even "creator and father" (273 B 1-2). During the first of the alternating world-periods, God accompanies the world in its forward revolution (269 C 4-5, cit. supra); in other

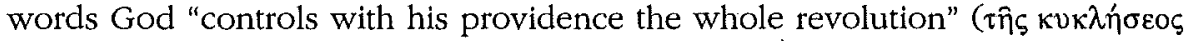

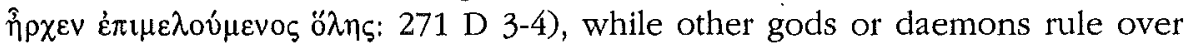
all the parts of the cosmos which are appointed to them (271 D - E 1). The famous king Cronus of the legend was just one of the attendant gods and was in charge of men (i.e. adult males without women or children) as "overseer"

3 Cf. J. ADAM, The Myth in Plato's Politicus, in CR (1891), p. 445. A detailed account of varying traditions by J.G. FRAZER, in Apollodorus, The Library, II (London-New York, 1921), p. 164-167, n. 1. A comment by P. VIDAL-NAQUET, Le mytbe platonicien du Politique, les ambiguttés de l'àge de l'or et de l'bistoire, in J. KRISTEVA (ed.), Langue, discours, société. Pour Émtle Benveniste, Paris, 1975 [ = Le chasseur noir, Paris, 1981, p. 369-370 ("Platon n'avait nul besoin d'évoquer ces inquiétants 'pasteurs' qu'étaient Atrée et Thyeste...") evidences the idiosyncrasies of his hermeneutics.

4 This Euripidean and Platonic concept of Zeus' Dike would appear characteristically nonGreek if we should generalize the conclusions of H. LLOYD-JONES, The Justice of Zeus, Berkeley-Los Angeles-London, 1971, p; 161-162: "Dike means basically the order of the universe, and in this religion the gods maintain a cosmic order. This they do by working through nature and the human mind, and not by means of extraneous interventions..."

5 LLOYD-JONES, op.cit. (n. 4), p. 163. 
and "shepherd"6. Consequently, God is rightly called the "pilot" or "steersman"

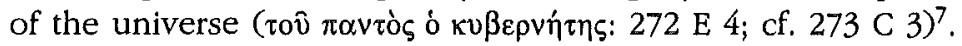

Let us now pass to God's negative activities, i.e. the moment of his noninterference in the cosmic affairs. When the cycles of the time appointed to it have accomplished their measure God lets the universe go to its destiny ( $\dot{\alpha} v \hat{\eta} \kappa \varepsilon v: 269 \mathrm{C} \mathrm{5}$ ), with the result that it begins to revolve in the contrary direction, of itself ( $\alpha$ v่ó $\mu \alpha \tau o v: 269 \mathrm{C} 7$ ). This backward revolution or rotation in reverse ( $\dot{\alpha} v \alpha \kappa \dot{\kappa} \lambda \eta \sigma \iota \varsigma)$ is providentially "the smallest possible alteration of the motion which pertains to it" (269 E 2-3). Elaborating on the nautical metaphor, Plato represents this behaviour of the god as that of a helmsman retiring from the steering-tiller of his boat. We are not told the reasons of the helmsman's departure. Since he is not conditioned by any necessity - ananke or beimarmene- but only by the nature of his models - the Ideas-, it is a matter of conjecture if he is bored, tired, worried, or ... sleepy. This may seem an academical question, but in fact it touches on the crucial point, i.e. the problem of God's freedom and/or responsibility in the government of this world. The following is the dramatic formulation of Plato's response to the mystery of God's attitude vis-à-vis the world. In the end God, the great

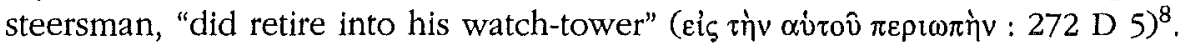
This standoffish attitude of the demiurge, which has such upsetting effects on the macrocosmos, has an impact on the human microcosmos as well. As soon as the world is abandoned by the supreme god, men are bereft of the care of the daemon (presumably to be identified with Cronus) who had got them to keep and tend (274 B 5-6) and lose also the watch kept over them by the other inferior gods (274 D 3-4).

6 For S. ROSEN, Plato's Myth of the Reversed Cosmos, in RMeta (1979), p. 74 (cf, 82), the demiurge and Cronus are one and the same, as is also the case with Zeus: "We have three different aspects of the same deity, of in a sense, a kind of Hegelian synthesis of the two opposites, Cronus and Zeus." This may be true at a metaphysically deeper level but goes beyond Plato's intentions, which in this case do not seem allegorical at all.

7 According to ADAM, art. cit. (n. 3), p. 446, the activities of the demtourgos and the kybernetes are in the last analysis coincident, that is, "the forward revolution of the universe... means nothing more of less than the creation of the world, t.e. its ordering out of chaos." According to Ch. MUGler, La physique de Platon, Paris, 1960, p. 170 (cf. 173, 178 and 192) -a drastically reductionistic approach- the god of the Pollticus myth is a symbol "pour l'information structurale du monde et le pouvoir régulateur qu'elle exerce sur les forces diffuses de l'ananke". For the problem of the Demiurge as a real person or as a mere symbol see the remarkable treatment by T.M. ROBINSON, Demiurge and World Soul in Plato's Politicus, in AJPh (1967), p. 5761, with which we fundamentally agree. For parallels with the Timaeus cf. P. FRUTIGER, Les mythes de Platon, Paris, 1930, p. 204; ROBINSON, art. ctt. (n. 7), p. 58 and 61.

8 To be compared to the similar but not identical formula in $7 \mathrm{im} .42 \mathrm{E}$ : when the Demiurge

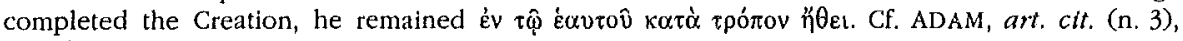
p. 446. 
What religio-historical interpretation is to be given to this myth of an alternate $^{9}$ withdrawal of God from the government of the world ${ }^{10}$ ? Some scholars doubt that this story can be taken in earnest, at least at a higher philosophical level ${ }^{11}$. Such scepticism is unjustified, for this myth - like all myths - contains no dialectical truth in itself but leads to the truth in a protreptical and analogical way ${ }^{12}$. However linked to the old tradition he might be (cf. $269 \mathrm{~B}$ and $271 \mathrm{~B}$ ), Plato nonetheless produced mythical lore by himself (cf. 269 C) for his own purpose. The impact of Plato as a myth-maker on the subsequent eschatological, psychological, cosmonical doctrines is well known in the case of the Phaedo, the Pbaedrus, the Timaeus. But even the Politicus myth had some reverberation on certain environments ${ }^{13}$

For instance, the theme of the "cosmetic" procedure that the returning god carries out on the decaying world may find a significant echo in Vergil's dream of the returning golden age: adspice convexo nutantem pondere mundum, /

9 According to Plato's cyclic view of time (pace Ch. MUGLER, Denx thèmes de la cosmologie grecque : devenir cyclique et pluralté des mondes, Paris, 1953, p. 93, 131, 139-143: see H. HERTER, Gott und die Welt bet Platon. Eine Studie zum Mytbos des Politikos, in BJ (1958) [= Kleine Scbriften, München, 1975, p. 328-329]; K. GAISER, Platons ungescbriebene Lebre, Stuttgart, $1968^{2}$, p. 393, n, 178), at the end of every cycle of backward revolution God "again takes up his post at the helm" (273 E 1), in order to restore the things which were gone the way of disease and dissolution during the time when the universe was left to itself.

10 For attempts at philosophical interpretation see J.A. STEWART, The Mytbs of Plato, London, 1905, p. 193-194; G. FRACCAROLI, "Introduzione", in Platone, Il Sofista e l'Uomo politico, Torino, 1911, p. 84; HERTER, art. cit. (n. 9), p. 325-326; MUGLER, op. cit. (n. 7), p. 188-189; ROSEN, art. cit. (n. 6), p. 80. L. BRISSON, Interprétation du mythe du Politique (Preliminary Paper presented at the Third Symposium Platonicum), Bristol, 1992, p. 4, emphasizes that "même lorsqu'il n'intervient pas directement, le dieu reste 'à la vigie'; il ne quitte donc jamais le navire auquel est comparé l'univers". But his re-intervention at the helm of the cosmos (273 E 1-4) does not take place before that the present period (that of Zeus) closes. During this period -that is our historical aeon- God is not at the helm of the universe (pace BRISSON, art. clt. [n. 10], p. 8 and passim), which proceeds

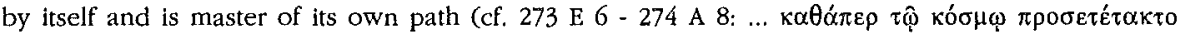

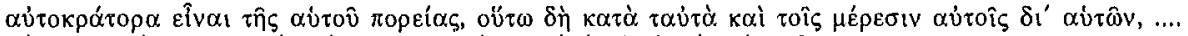

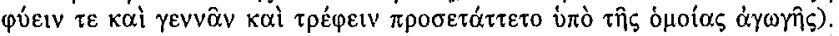

11 After Zeller, see esp. FRUTIGER, op. cit. (n. 7), p. 13, n. 2, p. 14, n. 1, p. 52, 167-168, 219, 220, n. 3, p. 279, 282, and A.E. TAYLOR, "Introduction", in Plato, The Sophist and the Statesman, London, 1961, p. 208-209. More reasonable the approach by STEWART, op. clt. (n. 10), p. 193-194; HERTER, art. cit. (n. 9), p. 318. Against the "overwhelming tendency in Platonic scholarship to take the figure of the Demiurge non-literally" we share MOHR's (op. cit. [n. 1], p. 40) poignant remarks: "These diverse strategies should be seen... largely as (unneeded) charitable attempts to distance Plato's thought from Christian thought and more generally as attempts to reduce the number of unfashionable theological commitments in Plato's cosmology."

12 In other words, "der Mythos ist der Wahrheit gegenüber ebenso vorlaüfig wie der Logos des Gesprächs, führt aber auf andere Weise, durch abbildhaft - umfassenden Wiedergabe, an die Wahrheit heran" (GAISER, op. cit. [n. 9], p. 419, n. 259). Cf. in general GAISER, p. 287-289: "Platon kann die althergebrachten Mythen übernehmen und seiner eigen Darstellung zugrundelegen, weil sie aus einer Zeit stammen, in der die Menschen noch die Möglichkeit der unmittelbaren Kommunikation mit dem Göttlichen hatten. Anderseits vermag er aber die Tradition von der philosophischen Prinzipienlehre aus erst grundsätzlich zu verifizieren" (p. 288).

13 For the limited fortunes of the Politicus within philosophical milieux see TAYLOR, op. cit. (n. 11), p. 249. 
terrasque tractusque maris caelumque profondum; / adspice, venturo laetantur ut omnia saeclo (Verg. buc. 4, 50-52) ${ }^{14}$. In Vergilius we have the same correspondence between macrocosmos and microcosmos as in Plato: as a result of the (initially wawering) shift of direction of the cosmos (mundus), a general restoration of the condition of the world will take place (cf. v. 6: iam ... redeunt Saturnia regna).

What is most remarkable in the Politicus myth, however, is the image of the "absent god", because in Plato's view the period of God's retirement is our present time, in which the course of historical events takes place ${ }^{15}$. This Platonic concept of God's absence from the government of the world is elaborated in an original way by the Middle Platonic Numenius (2nd cent. A.D.). He distinguishes between a first God (corresponding to Plato's Idea of Good) who is utterly inactive ( $\alpha$ prós: Num. fr. 12, 13 des Places) and quiescent ( Num. fr. 15, 3 des Places) and a Second God (corresponding to Plato's demiurge: Num. fr. 12, 2.14 des Places) who creates the world (Num. fr. 16, 11 des Places). But even the Second, ontologically inferior God cannot remain long at the level of created things. He confines himself to animating the beings with

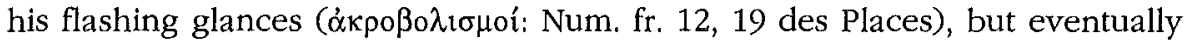

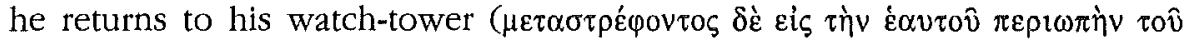
$\theta \varepsilon o \hat{v}$ : Num. fr. $12,19-20$ des Places, where the imitation of Plato is patent in its literality) in order to devote himself entirely to contemplation ("̈ $\pi \varepsilon \imath \tau \alpha$

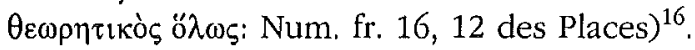

The gnostic Justin is a contemporary or an epigone of the Middle Platonic Numenius ${ }^{17}$. In the myth told in his Book Barucb Numenius' First God (the Idea of Good) corresponds to Justin's One above all, called the Good (o $\dot{\alpha} \gamma \alpha \theta \theta^{\prime} \varsigma$ ), at one point identified with cosmic Priapus; while Numenius' Second God (the demiurge) finds his pendant in Justin's Father of all begotten things, called Elohim. The Good, though taking forethought for the universe

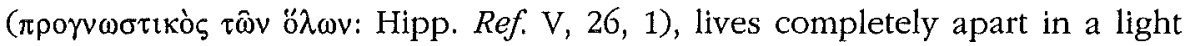

14 Cf. A. GRILLI, Pitagoreismo e non nella IV ecloga, in Atti del convegno virgiliano di Brindisi nel bimilleanario della morte. Brindisi 15-18 ott. 1981, Perugia, 1983, p. 299-300. I agree with this scholar that this conception should not be confused with the Pythagorean epanodos, anakyklosis or palingenesia (cf. PORPH., Vita Pytbag., 19, which should be integrated into DICAEARCH., fr. 33 Wehrli). Cf, also U. BIANCHI, Il 'Prima' e l' 'Altrove', in Kernos, 1 (1988), p. 1213.

15 Cf. S. PÉTREMENT, Le dualisme chez Platon, les gnostiques et les manicbéens, Paris, 1947 [reprint Brionne, 1982], p. 48: "Le Dieu suprême, pour Platon, est un Dieu lointain."

16 See the literature discussed by É. DES PLACES in Numenius, Fragments, Paris, 1973, p. 10-14; G. REALE, Storla della filosofia antica, IV, Milano, $1981^{3}$, p. 416-422.

17 Cf. S. LILla, s.v. Giustino gnostico, in A. DI BERARdino (ed.), Dizionario patristico e di anticbità crtstiane, Casale Monferrato, II, p. 1633-1634. For a more detailed analysis and bibl. see J. MONTSERRAT-TORRENTS, La philosopble du Livre de Baruch de Justin, in SP XVIII, 1 (E.A. LIVINGSTONE ed.), Kalamazoo (Mi), 1985 [but 1986], p. 253-261; G. CASADIO, Donna e simboli femminili nella gnost del II secolo, in U. MATTIOL (ed.), La donna nel pensiero sristiano antico, Genova, 1992, p. 305-329, esp. 307-308. 
palace at the upper limit of heaven (Hipp. Ref. V, 26, 15). Elohim, once he has created the world through mutual satisfaction following his copulation with Eden (= the Earth, the Matter, or rather the world-soul), desires "to ascend to the highest parts of heaven and to see if anything is lacking in the creation" (Hipp. Ref. V, 26, 14), Ultimately fallen under the control of the Good, Elohim is no longer able to and/or willing to descend to Eden -out of the metaphor he is decided to leave the world to itself (Hipp. Ref. V, 26, 20).

The gods of Justin - the former absent, the latter withdrawing from the world - are typical representatives of the godhead as conceived in a gnostic ideology: unknown, remote or estranged ${ }^{18}$. More specifically, both Elohim and the demiurge of Plato in the Politicus myth (as well as - to a lesser degreehis counterpart in the Timaeus myth) abandon their creation after having accomplished their task. So, from a broader comparative point of view, the gnostic god and the Platonic god may be considered characteristical examples of the phenomenological category of the deus otiosus ${ }^{19}$. The type of the deus otiosus is in fact attested by extensive and world-wide evidence from the cults of non-literate peoples and -with some distinctions- even from the more developed pantheons of Indo-European and Semitic peoples ${ }^{20}$. The phenomenology of the so-called "high gods" was firstly outlined by the Lutheran historian and phenomenologist of religion N. Söderblom (Das Werden des Gottesglaubens, Leipzig 1916 $1926^{2}$ ), who also pointed out the connection between the otiositas of these creators and the stability of the cosmic order (compare the apparent paradox in the behaviour of Plato's demiurge vis-âa-vis the world). The Supreme Beings are in fact personifications of an order which primitive man finds in the world. But the Supreme Being does not need to be concerned with it, as he has established everything perfectly ab antiquo. The mythical past is more important than the present historical situation: as an archetype the former leads and moulds the latter. Therefore the Supreme Being, creator of the world and founder of the laws and rites, takes on the attitude of deus otiosus, i.e. of a god who, once he has defined the fundamental principles of the cosmos, definitevely drops all interest in worldly affairs. This Being has ultimately only a second role in the religious life of mankind. This Heavenly Being is static like the sky from which currently he takes his name, and in which he lives. He is a deus otiosus, who only now and there becomes animated owing to the uranian-meteoric phenomena: rain, wind,

18 Cf. PÉTREMENT, op. cit. (n. 15), p. 47 and 160-163: "Celte étrange religion gnostique est un athéisme en ce qui concerne le monde. Le Dieu qu'on vénère est un dieu séparé du monde, et le monde se développe sans lui" (p. 163).

19 The case for Elohim as deus otiosus was already stated by K. KVIDELAND, Elobims Himmelfabrt, in Temenos (1964), p. 68-78, esp. 69. The parallels in Plato and Numenius disprove her attempt to demonstrate the Jewish origin of this gnostic myth.

20 Cf. G. CASADIO, El and Cosmic Order: ts the Ugaritic Supreme God a deus otiosus?, in Mytbology and Cosmic Order, Helsinki, 1987 (Studia Fennica, 32), p. 45-58; ID., A ciascuno Il suo: otium e negotium del dio silpremo dalla Siria alla Mesopotamia, in SMSR (1992), p. 59-79. 
rainbow, thunder, lightning, thunderbolt, dew, fog, and hail. But this apparently impassive, languid and slothful Being is the creator and the first regulator of sky, earth, vegetation, and mankind: as all-seeing and all-knowing (and as guardian of the order set up by himself) he is also the chastiser of various human trangressions. In fact, this god is "otiose" only in comparison to the activism of minor deities; and his indifference towards the human kind after creation is quite relative and does not impair his autority and primacy above all other gods. This apparently paradoxical otiositas might indeed belong to the essential nature of the Supreme Being and be in a way the complement of his creative activity. The world once made and the cosmos established, the creator's work is as good as done. Any further intervention on his part would be not only superfluous but possibly dangerous, since any change in the cosmos might allow it to fall back into chaos. The otiositas of the creator is the most favourable condition and the one naturally best suited to maintain the status quo (Plato's view is remarkably the opposite).

After this synoptic presentation of phenomenological data pertaining to the typology of the deus otiosus, with special reference to the lore of non-literate peoples, we should be able to outline the traditional world-view or so-to-say the substratum upon which Plato constructed his non-traditional representation.

\section{God and the Evil in the world}

In the last analysis, Plato advances the supposition of God's intermittent agency on this world in order to supply a cause (mythological, of course) for the existence of evil, both physical and moral, in a world supposed to be governed by a god altogether good, unresentful, and provident (cf. Tim. $29 \mathrm{E}-$ 30 B). In other words, the Politicus myth, like the Timaeus (esp. 28-48) and the Laws X (esp. 899-905) offers a solution to the problem of theodicy ${ }^{21}$. Plato, giving a thelogical reason for the existence of evil in light of the existence of God, who is good and-within the limits of convenience ( $\tau$ ò $\pi \rho 0 \sigma \hat{n} \kappa o v: 269 \mathrm{C}$ 6) - omnipotent, has not yet identified expressly the active cause of evil. In view of Plato's theodicy, the efficient cause of evil cannot in any case be attributed either to the action of God "creator and father"22 or the counteraction of a sort of "antagonistic" god ${ }^{23}$. For Plato, the actual source of evil is in fact endogenous to the phenomenal world.

21 Cf. STEWART, op. cit. (n. 10), p. 193-194 and 197-198.

22 This denial, explicit in $269 \mathrm{E} 8-9$, is implicit in the whole of the myth proclaiming the absolute goodness of God.

23 This view is explicitly denied in 270 A $1-2$. The denial of the existence of a couple of gods turning the world with conflicting purposes means a denial of Zoroastrian dualism. Zoroaster is well known to Plato (cf. Alc.I, $121 \mathrm{E}-122 \mathrm{~A}$; if this dialogue is by Plato: on the question of the authenticity see A.E. TAYLOR, Plato, London, 1926, $1960^{7}$, p. 522-523; W.K.C. GUTHRIE, Socrates, Cambridge, 1971, p. 150, n. 2); and his doctrine of the two conflicting divine principles found a remarkable echo in two of Plato's closest associates: Eudoxos (fr. 341 Lasserre: discussion with bibl. 
Let us now review the formulas that Plato employs in the Politicus myth to identify the source (or sources) of cosmic disorder which ultimately coincides with evil. According to Plato, disorder is symbolized by the retrogade motion of the universe. This backwards ( $\dot{\alpha} v \alpha \pi \alpha \lambda$ iv) circuit "belongs of necessity to the

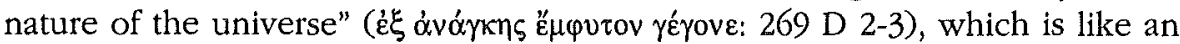

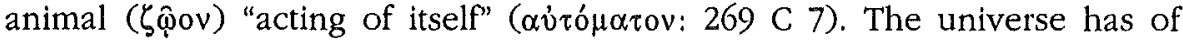
course been created good by the demiurge but "also partakes of body"

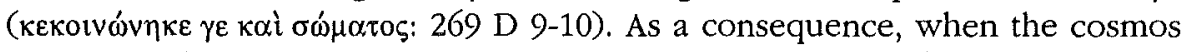
is let go and "moves of itself" ( $\delta t^{\prime}$ é $\alpha v \tau 0 \hat{v} \alpha$ vò̀v iéval: 270 A 5-6), it "proceeds in the contrary direction" (270 A 6-7). The reason because the cosmos started to revolve backwards is unambiguously asserted once again: it was an "impulse (or urge) decreed by fate and inborn" ( ultimate source of this impulse lies in a factor which is a "thing reared toghether

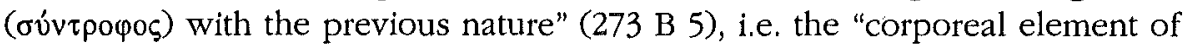

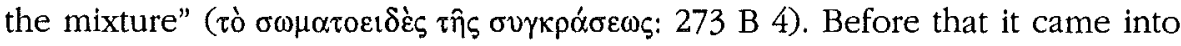
the present order, the nature of things was in fact "partaking of much disorder"

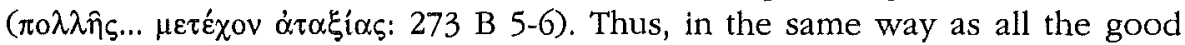
things of this world derive from the demiurge, all the harsh and unrighteous ones come from this previous state of ataxia (273 B 7 - C 1). Therefore, after the separation of the universe from its creator, "oblivion" $(\lambda \dot{\eta} \theta \eta$ : $273 \mathrm{C} 6)$ grew

by LASSERRE, ad loc., p. 254-256) and Aristoteles (fr. 6 Ross: cf. M. UNTERSTEINER, in Aristotele, Della filosofia, Roma, 1963, p. 81-86; GAISER, op. cit. [n. 9], p. 243-244 and 400, n. 209). Criticism of the Zoroastrian doctrine of the Ohrmuzd and Ahriman implies in some way a conscious of semiconscious reception of Persian lore. On this long-debated question, see esp. W.J. GOODRICH, Plato, Politicus 269 E - 270 A. An Allusion to Zoroastrianism?, in CR (1906), p. 208-209 (reception via Empedocles deriving himself at least a suggestion "from the same Persian dualism"?); R. REITZENSTEIN, Vom Damdad-Nask zu Plato, in ID. und H.H. SCHAEDER, Studien zum antiken Synkretismus aus Iran und Griecbenland, Leipzig-Berlin, 1926, p. 34-35 (Plato derives from Iran a number of motifs, "ohne doch den schroffen Dualismus der iranischen Lehre anzunehmen"); FRUTIGER, op. cit. (n. 7), p. 243 and n. 4 (prudent); P.-M. SCHUHL, Sur le mythe du Politique, in $R M M$ (1932), p. 57-58 ("ces questions d'influence sont délicates et souvent obscures"); J. BIDEZ, Eos ou Platon et l'Ortent, Bruxelles, 1945, p. $72-77$ and 97 ("Une forme de dualisme qui ne s'est pas constituée sans une certaine notion de celui de l'Iran"); A.J. FESTUGIÈRE, Platon et l'Ortent, in RPb (1947) [ E Etudes de philosopbie anctenne, Paris, 1971, p. 77-78] (Plato did not ignore the Iranian dualism and borrowed some traits from it, but "il ne doit qu'à lui seul la manière dont il conçoit et formule le problème du mal, puisque cette formule, et c'est là son mérite, n'est pas de l'ordre du mythe, mais proprement et purement philosophique"); F. ADORNO, Dialettlca e politica in Platone: saggio sul Politico e sulle Leggi, in AATC (1955), p. 137, n. 2; MOHR, op. cit. (n. 1), p. 152. On the side of Iranian scholarship see esp. J. DUCHESNE-GuILLEMIN, Obrmad et Abriman. L'aventure dualiste dans l'antiquité, Paris, 1953, p. 100, who pertinently remarks that in Plato's myth, "contrairement à la doctrine iranienne, la succession est cyclique, éternelle"; and ID., in Les religions de l'Ortent ancten, Paris, 1957 (ital. transl. Catania, 1960), p. 180: "Platone allude forse alla dottrina iranica, ma solamente per confutarla". Despite his Platonic affiliation, Plutarch (de Is. Os., 45 [369 C]; 49 [371 A] posits two principles (arcbal) or forces (dynameis) which look very much like the two Persian antithetical gods (as Plutarch explicitly admits: de Is. Os., 46-47). But in the

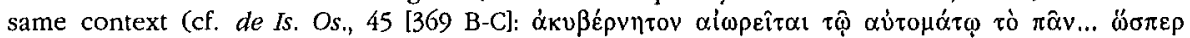
ol $\alpha \xi_{1 v}$ ) he links his own theistic dualism to Plato's non-theistic dualism of the Politicus myth (cf. F.P. HAGER, Die Materie und das Böse tm antlken Platonismus, in $M H$ (1962), p. 81; U. BIANCHI, Plutarco e $i$ d dualismo, in F.E. BRENK - I. GALLO (eds.), Miscellanea plutarchea. Atti del I convegno di studt su Plutarco (Roma, 23 nov, 1985), Ferrara, 1986, p. 115). 
more and more in it until "the influence of the ancient discord" ( $\tau$ ò $\tau \eta \varsigma \varsigma \alpha \alpha \lambda \alpha \hat{\alpha} \varsigma$ $\dot{\alpha} v \alpha \rho \mu \circ \sigma i \alpha \varsigma \pi \alpha \dot{\theta} \theta$ os: 273 C 7 - D 1) prevailed.

So, at least in the Politicus myth, the ultimate source of evil is to be

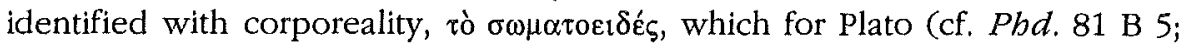
Resp. VII, 532 C 7; Tim. 31 B 5) is virtually equivalent to phenomenal reality, But neither is the corporeal as such coincident with the evil, nor does the evil originate from the corporeal in $s^{24}$. The evil rather derives from a factor which is originally inherent in the precosmical reality - the ataxia ${ }^{25}$ or anarmostia ${ }^{26}$ which pertains to original chaos ${ }^{27}$.

24 Cf. ROBINSON, art. cit. (n. 7), p. 63: "It can mean simply that in any complew involving body or the bodily, results tend to be less perfect than in a complex which does not."

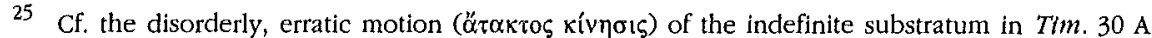
and of the universe guided (but it is just a hypothesis which involves a reductio ad absurdum: cf. FESTUGIÈRE, art. cit. [n. 23], p. 73, and TAYLOR, op. cit. [n. 11], p. 210) by an evil soul in Leg. X, 897 D 1 and 898 B 5-8.

26 "Discord" or "dissonance", which is the contrary of barmonia (= arete) and virtually coincident with evil (kakia): Phaed., 93 E 6 (a Pythagorean view, of course).

Cf. FRACCAROLI, op, cit. (n. 10), p. 83; K. REINHARDT, Platons Mytben, Bonn, 1927 [= Vermächtnis der Antlke, Göttingen, $1966^{2}$, p. 272); FRUTIGER, op. cit. (n. 7), p. 189 ("le mouvement inverse ou spontané est, avec toutes ses conséquences fâcheuses, l'héritage du désordre originel, de l'état antérieur à l'activité du démiurge"); A. DIÈs, "Notice", in Platon, Le Polttique, Paris, 1935, p. XXX-XXXII; BIDEZ, op. cit. (n. 23), p. 176, n. 15; PÉTREMENT, op. cit. (n. 15), p. $45-47$ ("le mouvement, cet ordre naturel, qui n'est aux yeux de Platon qu'un désordre, paraît bien être pour lui la cause du mal"); FESTUGIÈRE, art. cit. (n. 23), p. 71-72 and 74 (the source of evil in the "nature corporelle avant que le monde n'ait été organisé en cosmos"); CHERNISS, art. cit. (n. 2), p. 255, n. 21 and p. 259, n. 44 (see the more general statement p. 257: "Positive evil in the world, both absolute and relative, is produced by the misguided motion of evil souls" and cf. the bibl. on the most controversial subject of the source(s) of evil p. 253, n. 1); ADORNO, ant. clt. (n. 23), p. 140-141; HER'TER, art. ctt. (n. 9), p. 319-323 ("so darf man schliessen, dass die Weltseele von dem Drange ihres Körpers zur Umkehr irgendwie infiziert ist": p. 322); MUGLER, op. cit. (n. 7), p. 167, 169, 174 ("le sens rétrograde est produit par les mouvements non contrôlés de la matière, par l'automaton du flux matériel qui déborde ses digues"), p. 175, 177, 180 (force of necessity = force of inertia),

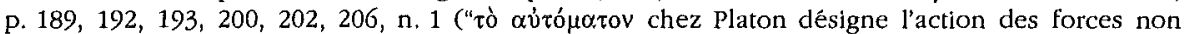
canalisées de la nécessité"); TAYLOR, op. cit. (n. 11), p. 209-210 (The Politicus, "like the Pbaedo, suggests what became the tenet of popular Platonism in later antiquity, that 'body' or 'matter' is the source of evil". But this contradicts the teaching of the Laws $896 \mathrm{D}$ on souls as the ultimate sources of all movement: cf. CHERNISS supra); HAGER, art. cit. (n. 23), p. 74 (the Politicus myth offers "die deutlichste Belegstelle für die Materie als Prinzip der Bösen'), p. 99-101 (against Proclus' attempt to demonstrate "dass mit dem $\sigma \omega \mu \alpha \tau o \varepsilon t \delta \varepsilon ́ \varsigma$ nicht die ü $\lambda \eta$ gemeint sei", and that "aus dem $\pi \lambda \eta \mu \mu \varepsilon \lambda \hat{\omega} \varsigma$

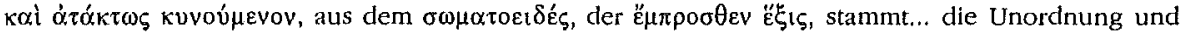
das Böse, aus der Bewegung der Materie, nicht aus der Materie selbst", he contends forcibly that

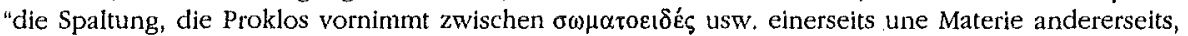
bei Plato selbst durch nichts gerechtfertigt ist"), and cf. p. 73-75 for a status quaestionts with bibl. about the problem of the source of evil according to Plato; ROBINSON, art. cit. (n. 7), p. 58 and 6264 ("the 'bodily' which accounts for the evil in the world... has some affinities with the Necessity of the Timaeus", and in this case "the evidence of the text seems to point to Plato's discomfort about the whole matter": p. 63); MOHR, op. ctt. (n. 1), p. 141-157 ("the corporeal on its own without psychical influences moves chaotically, is the efficient cause of the retrograde cycle of the universe, and is a positive source of disorder and evil" [p. 156], whereas "the World-soul itself, seems not primarily to be viewed as an efficient cause either of motion as such or of motion as regular or erratic" [p. 157]; see p. 142 for a discussion of the literature about the causes of "disorderly motion" 
If we now raise the question "was Plato dualist in the Politicus myth", we should answer without hesitation in the affirmative. In this myth Plato postulates in an unequivocally dualistic manner two opposing principles which lie at the root of all the phenomena of the universe. These principles are evidently the Demiurge on the one hand and the precosmical chaotic condition of the universe on the other. Both of them have reflections on the ethical level - the Good and the Evil respectively. But at the same time they are ontological principles and primary or secondary causes of all phenomena existing in the universe and determining its nature ${ }^{28}$. We may admit so much that the divine principle has a highest ontological status, and so this seems to be a relative or mitigated dualism in which one principle is subordinated to the other. In this system, however, Demiurge (the active ordinator) and Chaos (the passive ordinandum) "are and remain opposed to one another and cannot be derived from or reduced to each other" 29 . The two principles seem to be also coeternal, in the sense that both of them exist and act from the very beginning. If we insist, as does U. Bianchi ${ }^{30}$, on the coeternality of the principles, disregarding the fact that they are not coequal, we may even consider Plato's dualism to be radical, notwithstanding the rejection that such an assertion would raise in many eminent Platonists.

in the Politicus); BRISSON, art. cit. (n. 10), p. 4 ("le renversement de la révolution cosmique s'explique par le mouvement de l'âme du monde qui se trouve, elle, sous l'influence du corps").

28 This was also the opinion of Aristoteles (Metapb. I, 6, 988 A 7-17), who points out in Plato's system two principles ( $\sigma \tau \circ \chi \chi \varepsilon \hat{\alpha} \alpha$ ) which represent the Good and the Evil. Cf. the sharp criticism by HAGER, art. cit. (n. 23), p. 75-76: "Das materiell körperliche kann nach unserer Platointerpretation niemals dem ordnenden Geistigen als gleichberechtigte Wesenheit und gleich Mächtiges Aufbauprinzip des Alls zur Seite treten... Genau so wenig wie das materialprinzip dem Geistprinzip gleichberechtigt gegenübertritt (und dies allein wäre wahrer Dualismus), genau so wenig tritt nach Plato auch das Böse dem Guten gleichberechtigt gegenüber". For other references to Plato's dualism as envisaged by Aristoteles see GAISER, op. cit. (n. 9), p. 243 and 400, n. 209. Among modern advocates of dualism in Plato with reference to the Politicus cf. PÉTREMENT, op. cit. (n. 15), p. 118: "Ainsi le corps, ou plutôt le principe corporel, sans être le mal, est le principe du mal"; FESTUGIÈRE, art. cit. (n. 23), p. 68: "Le dualisme platonicien est l'opposition d'un principe du bien et de la matière", and this "dualité du bien et du mal se retrouve dans le mythe fameux du Politique" (p. 71); GAISER, op. cit. (n. 9), p. 212, 243-244, 284 ("der zeitlose Gegensatz der Grundprinzipien, Peras und Apeiron"), p. 391, n. 173 ("die Spannung zwischen Nus und Epithymia in der Seele ergibt sich aus der Mittelstellung zwischen Idee und körplicher Erscheinung, Einheit und unbestimmter Vielheit"); BIANCHI 1986, art. cit. (n. 23), p. 115-116 and n. 19, defining the Platonic dualism as "dialettico e, misuramente, procosmico"; ID. Per la storia del dusalismo in Grecia, in La soteriologia del cristianesimo. Ricerche storiche comparative, Roma, 1992, p. 39-52, spec. p. 51-52: according to Plato, the evil has an ontological character in the context of a dualistic system, "essendo espresso come un prestabilito defectus di valore a carico dei livelli inferiori dell'universo", and despite the fact that we do not ascertain the existence "di una sostanza attiva o maligna, una sostanza a tutto tondo, una sostanza per così dire 'in convesso'."

29 P.F.M. FONTAINE, The Light and the Dark. A Cultural History of Dualism, III, Amsterdam, 1988 , p. 180 (for an interesting -even in some cases superficial-treatment of the general topic of Plato's dualism see p. 119-182).

30 S.v. Dualism, in M. ELIADE (ed.), The Encyclopedia of Religion, New York-London, 1987, IV, p. 506-512: 507-508. 


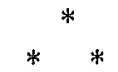

There is another aspect of the Politicus myth which is of major relevance to the history of religions. This is to be recognized in its concern for mankind's history, with the ambiguities intrinsic to its course (the idea of progress and/or regress as reflected in the legends of the gegeneis, Golden Age, Cronus' kingdom). But all this intriguing matter ${ }^{31}$ cannot be debated now given the narrow scope of this paper.

Giovanni CASADIO

Dipartimento di Scienze dell'Antichità

Università degli Studi di Salerno

I - 84084 FISCIANO (SA)

31 See the contribution of VIDAL-NAQUET, art. cit. (n. 3), and M. TULLI, Età di Crono e ricerca sulla natura nel Politico di Platone, in SCO (1990), p. 97-115. Both of them -for one reason or another- are unsatisfying from a religio-historical point of view. 